\title{
INDIKATOR PENANAMAN NILAI-NILAI PAK DALAM KELUARGA BAGI PERBINAAN IMAN ANAK REMAJA DI ZAMAN NOW
}

\author{
Magdalena Grace Kelly Tindagi
}

\section{PENDAHULUAN}

Manusia yang hidup di zaman now ini, dilanda oleh gejala atau faktor yang sangat mempengaruhi norma-norma moral yang melibatkan tindakantindakan etisnya di dalamnya, sebagai akibat dari perkembangan ilmu pengetahuan dan teknologi. Laju perkembangan arus informasi dan teknologi secara bersamaan, memberikan pengaruh pada perkembangan remaja sebagai suatu masa "krisis identitas" dalam pencarian identitas diri sebagai individu yang utuh. Berbagai sarana dan prasarana penunjang seperti; fasilitas alat telekomunikasi (cetak maupun elektronik), keberadaan orangtua dan keluarga serta teman sebaya. Seluruh komponen mempengaruhi bagaimana proses terbentuknya identitas diri sebagai individu yang utuh.

Bagi remaja sarana dan prasarana penunjang tersebut memiliki arti yang berbeda-beda, pada remaja tersebut dapat dialaminya sebagai faktor pendukung, namun bagi remaja lainnya dapat diartikan sebagai faktor yang menghambat perkembangannya. ${ }^{1}$

Mengacu pada arus informasi yang sangat pesat saat ini menyebabkan remaja dihadapkan pada berbagai informasi di lingkungannya. Masa remaja merupakan masa transisi dan peralihan dari masa anak-anak ke dewasa, terdapat beberapa istilah yang biasa digunakan dalam masa peralihan antara masa kanak-kanak ke masa dewasa, yaitu "pubertas" (adolescence), istilah "remaja" merupakan terjemahan bahasa Latin "adolescere" yang berarti "to growth" atau "to grow to maturity". 2 Pandangan Stanley Hall, yang dikutip Gunarsa menyatakan bahwa masa remaja merupakan masa penuh gejolak emosi dan ketidakseimbangan yang tercakup dalam "storm dan stress". 3 Dan

\footnotetext{
${ }^{1}$ Muktar, Niken Ardiyanti, Erna Sulistiyanngsih, Konsep Diri Remaja, (Jakarta: PT. Rakasta Samasta, 2001), v

${ }^{2}$ S.W Sarwono, Psikologi Remaja, (Jakarta: Rajawali, 1989), 4-15

${ }^{3}$ Singgih D. Gunarsa, Psikologi Muda-mudi, (Jakarta: BPK. Gunung Mulia, 1989), 205
} 
menurut Sarwono ada tiga jenis lingkungan yang sangat berpengaruh dalam kehidupan remaja yaitu; lingkungan keluarga di mana remaja sebagai anggota, lingkungan sekolah, dan lingkungan masyarakat. ${ }^{4}$

Di zaman now ini juga, menuntut bahwa pola asuh dan peranan orang tua dalam keluarga sangat penting dalam membentuk pribadi anak. Perlakuan orang tua dalam mengasuh anak sangat menentukan perilaku yang pro sosial atau anti sosial. ${ }^{5}$ Hoffman membedakan pola asuh orang tua atas tiga kelompok yaitu: pertama, pola asuh bina kasih (Introduction), di mana orang tua memberikan penjelasan agar anak mengubah tingkah lakunya yang negatif; ke dua, pola asuh unjuk kuasa (Power Assertion), yaitu cara orang tua mengasuh dengan memperlihatkan perilaku yang membuat anak merasakan tekanan dari luar sehingga berperilaku sesuai kehendak orang tua; ke tiga, pola asuh lepas kasih (Love Withdrawal), yaitu cara orang tua mengasuh dengan memperlihatkan pernyataan-pernyataan kemarahan atau ketidaksetujuan orangtua terhadap anak yang sifatnya non fisik dengan implikasi bahwa kasih sayang tidak dipulihkan sampai anak berperilaku sesuai kehendak orang tua. Namun demikian dalam kehidupan sehari-hari sebenarnya pengasuhan yang dilakukan orangtua dapat saja memperlihatkan kasih sayang pada anak, pada saat yang lain dapat pula menunjukkan hal yang sebaliknya. ${ }^{6}$

Realitas anak remaja di zaman now ini, sangat rumit keadaan dan kondisinya serta memang perlu dihargai, dibimbing, dan hidup dalam suasana yang menyenangkan, agar dapat keluar dari berbagai permasalahannya. Pada saat tertentu, anak perlu juga diperintah, dan kalau salah perlu ditegur. Selain itu anak perlu diberikan ruang kebebasan yang cukup sehingga dapat aktif dan kreatif, untuk situasi ini diperlukan pemahaman yang utuh mengenai keberadaan keluarga Kristen sebagai bangunan dasar iman bagi anak remaja tersebut. $^{7}$

\footnotetext{
${ }^{4}$ S.W Sarwono, Psikologi Lingkungan, (Jakarta: Grasindo, 1992 ),111-128

${ }^{5}$ Menurut Elisabet Hurlock, terdapat empat pola dasar yang bipolar tentang hubungan antara orangtua dengan anak, yaitu: a).toleran-tidak toleran b). permisif- keras, c). membiarkan- turun terlibat dan, d). hubungan dingin-hubungan hangat. Elisabeth Hurlock, Personality Development, (New Delhi: McGraw-Hill Publishing Co,Ltd,1974,) 353

${ }^{6}$ M.L. Hoffman, Conscience, Personality and Socialization Techniques In Human Development, 1970), 92-126

${ }^{7}$ Menurut Elida Prayitno seperti yang dikutip Garang, bahwa pola pendidikan demokratis adalah orang tua yang hangat, menunjukkan kasih sayang yang mendalam dan memperhatikan kepentingan anak. Akibatnya anak mandiri memiliki keyakinan yang tinggi dalam mengerjakan tugas, tidak putus asa, tidak takut berbuat salah, terbuka dengan orang lain dan mudah diterima oleh teman-temannya, Bambang T.K Garang, Disertasi..23 Band. S. Nasution, Berbagai Pendekatan Dalam Proses Belajar-Mengajar, (Jakarta: Bina Aksara, 1982), 114-120
} 


\section{INDIKATOR PENANAMAN NILAI-NILAI P.A.K. DALAM KELUARGA}

Keluarga adalah lembaga sosial pertama yang dikenal anak dalam proses sosialisasinya. Keluarga terutama orang tua sangat besar pengaruhnya terhadap perkembangan kepribadian anak, termasuk pola asuhan orangtua yang diterapkan pada anaknya. Affandi menyatakan banyak perilaku menyimpang, seperti kriminalitas, kecanduan obat dan sebagainya yang penyebabnya dapat dicari di dalam keluarga. Pola hidup keluarga, termasuk pola asuhan orangtua, dapat dipakai sebagai salah satu faktor untuk memprediksi penyebab perilaku menyimpang tersebut. ${ }^{8}$ Diuraikan juga oleh Stepen Tong bahwa akibat perubahan zaman, anak-anak jadi mudah memberontak dan melakukan tindakan tak bermoral, anti keluarga, anti-orang tua, baik di sekolah maupun di media. ${ }^{9}$ Dalam fase perkembangan kebanyakan anak remaja tidak mampu lagi menahan segala macam gejolak dan gelombang pengalaman hidup yang menyebabkan menderita dan kebingungan. Dalam kondisi yang sangat kompleks tersebut, pendidikan Agama yang diberikan kepada anak remaja merupakan indikator utama untuk penanaman nilai-nilai iman. ${ }^{10}$ Menurut Nuhamara, anak-anak dalam keluarga Kristen melalui interaksinya dengan kedua orangtuanya akan mengalami sosialisasi, yang pada gilirannya membentuk identitas diri seorang anak menjadi identitas diri yang Kristen. ${ }^{11}$

\section{Melibatkan Semua Unsur di dalam Keluarga dalam Mengajar Anak}

Dalam bahasa Ibrani terdapat beberapa istilah yang dapat diterjemahkan dengan kata "keluarga", yakni cerita mengenai Akhan dalam kitab Yosua (Yos 7:16-18). Dalam kisah ini Akhan disebut berasal dari "suku" (syebet) Yehuda, dari "kaum" (mysypakha) Zerah, dan dari "keluarga" (bayit) Zabdi. Jadi ada tiga istilah yang saling berkaitan dalam pengertian keluarga, yaitu: syebet, misypakha, dan bayit. Dengan demikian diketahui bahwa Akhan sebenarnya telah berkeluarga, dan meskipun sudah menikah, namun masih dimasukkan ke dalam keluarga (bayit) neneknya Zabdi (band Yos 7:24). Jadi kata syebet dan misyphaka dapat diartikan dengan kaum, marga atau suku

${ }^{8}$ Danny Yatim Irwanto, Kepribadian, Keluarga dan Narkotika, (Jakarta: Penerbit Arcan, 1993), 94

${ }^{9}$ Stephen Tong, Keluarga Bahagia, (Surabaya: LRII, 2007), 3

${ }^{10}$ Sudarsono, Kenakalan Remaja, (Jakarta: Rineka Cipta, 1995), 156

${ }^{11}$ Daniel Nuhamara, Pembimbing PAK, (Bandung: Jurnal Info Media, 2007), 62 
(band. Hak 18:11). Sedangkan istilah Ibrani untuk keluarga yang sering diterjemahkan ke dalam bahasa Indonesia adalah kata bayit . Kata bayit dapat diterjemahkan dalam arti rumah maupun bangunannya, juga mencakup seluruh penghuni rumah atau bangunannya, misalnya Abraham dan orang-orang terlatih yang lahir di rumahnya disebut sebagai keluarga (Kej 14:14). ${ }^{12}$

Beberapa istilah dalam bahasa Yunani yang diterjemahkan dengan kata keluarga yakni kata Oikos, kata ini lebih sering diterjemahkan dengan kata keluarga, rumah, rumah tangga. Kata Oikos juga sejajar dengan kata bayit dalam bahasa Ibrani, juga sering diterjemahkan dengan kata keluarga atau keturunan (1 Tim 5:4,8; Tit 1:11, bd. Luk 1:27,69). ${ }^{13}$ Berikutnya kata patria, kata ini sejajar dengan kata misyphaka (Ibr.) dengan arti keturunan, contoh Yusuf disebut sebagai (patria) Daud. Kata patria juga diartikan dengan kata leluhur, dalam arti suku atau semua bangsa di bumi ( Kis 3:25) dapat juga diartikan dalam pengertian seluruh umat manusia (Ef 3:14) yang konotasinya bahwa semua keturunan (patria) adalah berasal dari Allah yang disebut sebagai Bapa.

Selanjutnya dalam Perjanjian Baru ada kata genos yang diartikan keluarga. Kata genos lebih menunjuk kepada keturunan dari satu nenek moyang atau penunjuk kepada satu keluarga, suku bangsa. ${ }^{14}$ Jadi keluarga adalah persekutuan yang dibentuk oleh seorang suami dan seorang isteri beserta dengan anak-anak, di mana mereka tinggal dalam satu rumah.

Dengan demikian pergumulan utama keluarga di zaman now adalah peran dan pentingnya melibatkan semua unsur dalam keluarga dalam pengajaran. Perjanjian Lama memerintahkan dan memperkenalkan keunggulan pendidikan keluarga dalam menyebarkan iman dari satu generasi ke generasi berikutnya. Demikian juga Perjanjian Baru mendeskripsikan bahwa tempat pemeliharaan dan pelatihan iman terletak dalam keluarga. ${ }^{15}$

\footnotetext{
${ }^{12}$ Marulak Pasaribu, Pernikahan dan Keluarga Kristen, (Batu: Departemen Literatur YPPII, 2005)12-14

${ }^{13}$ Ibid., 14

14 Ibid.

15 Paulus Lilik K, Prinsip dan Praktik Pendidikan Agama Kristen Agama Kristen, (Yogyakarta. Andi Ofset, 2010), 124
} 


\section{Memiliki Peran Utama dalam Pemeliharaan Iman Anak}

Keluarga adalah lembaga pertama yang ditetapkan Allah di bumi. Allah mendirikan keluarga agar anak belajar dari orangtua. Sebelum membentuk jemaat dan sebelum ada pemerintahan, Allah mengukuhkan pernikahan dan keluarga sebagai bangunan dasar masyarakat. ${ }^{16}$ Landasan Alkitab dalam Kitab Ulangan 6:7-9 dapat disimpulkan dengan jelas mengenai peranan orangtua dan tanggung jawab mereka untuk memberitahukan setiap ketetapan Allah kepada anak-anak. ${ }^{17}$ Keteladanan orangtua adalah Injil yang dapat dilihat, dirasakan, dan dinikmati oleh anak. Keluarga Kristen adalah pemberian Tuhan yang tidak ternilai. Keluarga Kristen mengambil peran penting dalam Pendidikan Agama Kristen.

John Calvin mengatakan bahwa tujuan pemberian Pendidikan Agama Kristen bagi anak; yang pertama, adalah mendidik anak-anak dalam gereja agar terlibat dalam penelaahan Alkitab secara cerdas sebagaimana dengan bimbingan Roh Kudus; ke-dua, adalah menyiapkan anak untuk mengambil bagian dalam kebaktian dan memahami keesaan gereja; ke-tiga, memperlengkapi anak untuk memilih cara-cara mengejawantahkan pengabdian diri kepada Allah Bapa dan Yesus Kristus dalam pekerjaan sehari-hari serta hidup bertanggung jawab di bawah kedaulatan demi kemuliaaan-Nya sebagai lambang ucapan syukur yang dipilih dalam Yesus Kristus. ${ }^{18}$ Keseluruhan isi Alkitab telah menyaksikan bagaimana pentingnya keluarga yang dipakai Tuhan sebagai saluran dan jalan keselamatan yang dirancang Tuhan bagi umat manusia.

Ted Ward mengatakan bahwa keluarga Kristen dapat memilih satu dari tiga cara pandang keluarga, yakni: pertama, sebagai yang bertanggung jawab mengajarkan moral dan hal-hal rohani; ke-dua, sebagai sumber perkembangan moral dan rohani ; ke-tiga, memikul tanggung jawab utama. ${ }^{19}$

Keluarga Kristen atau orangtua percaya bahwa pemberian anak oleh Tuhan merupakan penugasan, pemberian mandat dari Allah terhadap orangtua, yakni, untuk mengasuh, mendidik anak-anak di dalam kasih dan pengampunan, mengenal jalan Tuhan dan bertumbuh dalam iman dan

${ }^{16}$ Harianto GP, Pendidikan Agama Kristen dalam Alkitab dan dunia pendidikan masa Kini, (Yogyakarta: Penerbit Andi, 2012), 66

${ }^{17} \mathrm{Ibid}$

${ }^{18}$ Paulus Lilik Kristianto, Prinsip dan Praktek Pendidikan Agama Kristen.......

${ }^{19}$ Ted Ward, Nilai Hidup di mulai dari Keluarga, (Malang: Gandum Mas, 1979),10 
kepercayannya kepada Allah (Ef 6:1-4; Kol 3:20; 1 Pet 2:9). ${ }^{20}$ Sesungguhnya, pendidikan dimulai dari keluarga. Anak harus dididik dan didorong untuk menerapkan semua nilai-nilai luhur sebagaimana diajarkan Firman Tuhan. Keluarga Kristen adalah pemberian Tuhan yang tidak ternilai, landasan Alkitabiah dalam Ulangan 6:4-9 menunjukkan bahwa orangtua berperan sebagai guru dan penginjil yang terus mengarahkan dan mendorong anak untuk hidup dalam Kristus. Menurut Efesus 6: 4, dasar penting dalam mendidik anak adalah keluarga yang berpusat pada Kristus.

Menurut John Mac Arthur sebagaimana yang dikutip Harianto, ada beberapa hal yang dapat dilakukan keluarga atau orangtua Kristen kepada anak-anak, yang pertama, mengajar anak-anak agar takut akan Tuhan (Ams 1:7;9:10); 2), ke-dua, menjaga pikiran anak-anak (Ams 4:23); ke-tiga, anakanak menaati orang tua (Amsal 1:8). ${ }^{21}$

\section{Membawa Pencapaian Nilai-Nilai Identitas Diri ("Identity Achievement") $\underline{\text { Anak }}$}

Menurut James Fowler bahwa pertumbuhan iman manusia itu mengalami penahapan. Secara khusus, di tingkatan atau taraf iman yang sinthetis konvensional usia 12-17 tahun di mana anak remaja membentuk pandangan hidupnya melalui apa yang dipercayai oleh keluarganya sendiri, ke arah pandangan lain di luar. Hal ini sejalan dengan makin meluasnya lingkungan perhatian remaja pada usia itu. Sering juga, pada taraf ini disebut taraf "konformis", dalam arti bahwa remaja "membebek" apa saja yag dikatakan dan penilaian orang lain. Namun di pihak lain remaja sendiri tidak yakin benar terhadap identitas diri sendiri dan kesanggupan menilai mana yang baik dan mana yang tidak. ${ }^{22}$

\footnotetext{
${ }^{20}$ Harianto GP, Pendidikan Agama Kristen dalam Alkitab dan dunia pendidikan masa Kini, (Yogyakarta: Penerbit Andi, 2012), 66

${ }_{21}^{21}$ Harianto GP, Pendidikan Agama Kristen dalam..., 69 .."Orangtua juga dapat mengajar anak untuk mengajak mereka ke gereja setiap minggu, mengajar mereka berdoa, membaca Alkitab dan mengadakan saat teduh bersama, sehingga pikiran dan hati nurani yang dikendalikan firman Tuhan menjadi sumber bagi sikap dan perilaku benar".

22 N.K Atmadja Hadinoto, Dialog dan Edukasi Keluarga Kristen dalam Masyarakat Indonesia, ( Jakarta: BPK. Gunung Mulia, 2010), 234. Fowler memberikan arti yang khusus terhadap kata 'Faith. "Faith, as approached here, is not necessearily religious; nor is it to be equated with belief. Rather, faith is person's way of learning in to and making sense of life. More verb than noun, faith is the dynamic system of images, vaues, and commitments that
} 
Masa remaja juga disebut masa pancaroba, yakni masa peralihan antara masa anak dan kedewasaan yang penuh dengan gejolak. Remaja mulai lebih berorientasi kepada kelompok sebaya dan cenderung mengidentifikasikan diri dengan mereka. Bila pada masa ini remaja belum memperoleh bekal nilai-nilai yang mantap dari orangtua/keluarga dan guru sebagai pedoman perilaku, maka remaja bisa mudah terpengaruh oleh perilaku negatif. ${ }^{23}$ Konsep diri berperan dalam mengatasi krisis identitas pada remaja. Seberapa jauh seseorang mempersepsikan kemampuan dirinya dalam situasi atau hal tertentu mengarahkannya untuk kemudian dapat berhasil atau tidak, dalam meraih apa yang diinginkannya, dengan pertimbangan norma-norma di masyarakat. Marcia menyatakan individu yang telah berhasil mengatasi krisis identitas memiliki identitas diri yang dinamakan dengan "Identity Achievment" yaitu keadaan di mana individu telah memiliki nilai-nilai pribadi yang diyakininya untuk kemudian digunakan sebagai dasar pengambilan keputusan dalam hidupnya. Seseorang yang sudah mampu mencapai identitas dirinya dapat dilihat dari komitmen yang mereka miliki dalam hidupnya, khususnya; komitmen dalam konteks pemilihan pendidikan, pekerjaan, dan pergaulan. ${ }^{24}$

\section{INDIKATOR PENANAMAN NILAI-NILAI P.A.K. DALAM KELUARGA BAGI PERBINAAN IMAN ANAK REMAJA DI ZAMAN NOW}

\section{Memegang Teguh Pengharapan akan Kehidupan Masa depan Anak}

Pendidikan iman dalam keluarga, harus dapat menolong remaja dalam memperoleh orientasi yang lebih luas, dan dalam mensintesiskan antara informasi dan nilai-nilai pendidikan Kristen dalam pembentukan identitas dan pandangan hidup anak di keluarga. Garang mengemukakan bahwa pelaksanaan pendidikan di keluarga itu meliputi banyak hal, antara lain yaitu pengetahuan dan keterampilan orangtua, tujuan yang ingin dicapai, prinsip-prinsip yang dianut. Semuanya itu saling berhubungan dan mempengaruhi satu dengan yang

guides one's life. It is thus universal: everyone who chooses to go on living operates by some basic faith..."

${ }^{23}$ Utami Munandar, dalam Weinata Sairin, Indentitas dan Ciri Khas Pendidikan Kristen di Indonesia, (Kumpulan Tulisan), (Jakarta:BPK.Gunung Mulia, 2000), 160

${ }^{24}$ Diane E. Papalia \& Sally Wendkos, Olds, Human Development, (Boston: McGraw - Hill Company Inc, 1998), 370-371 
lain, pola pendidikan anak yang dianut, serta frekuensi tindakan pendidikan membawa dampak yang berarti bagi pembinaan perilaku anak. ${ }^{25}$

Ajaran Alkitab untuk kehidupan berkeluarga mencakup berbagai petunjuk untuk anak, ibu, dan ayah. Dalam Alkitab, bahwa keluarga yang menaati Allah dan diberkati juga berbagai keluarga yang tidak mematuhi kehendak Allah akan menuai akibat-akibatnya. ${ }^{26}$ Pendidikan agama dalam keluarga merupakan dasar bagi seluruh pendidikan lainnya dalam masyarakat dari umat Tuhan pada zaman Perjanjian Lama, seperti yang disampaikan nabi Yeremia dari Yerusalem kepada para pemimpin bangsa Yahudi yang berada dalam tawanan di Babel yakni, mengajak supaya membangunkan rumah, membentuk rumah tangga, melahirkan dan membesarkan anak-anak, dalam rasa takut akan Tuhan, supaya umat Tuhan jangan mati merana, melainkan tetap berbiak dan berkembang karena justru dalam keluarga Yahudi itu terletak harapan dan jaminan masa depan yang hendak didatangkan Tuhan kelak. Seharusnyalah umat berdoa bagi keselamatan negeri tempat umat berdiam untuk sementara. Sehingga, dengan demikian iman akan terpelihara dan kesemuanya akan menantikan terwujudnya janji-janji Tuhan dengan hati tabah. ${ }^{27}$

Selanjutnya, di dalam Perjanjian Baru bahwa Tuhan Yesus telah mengatur pernikahan dan keluarga sebagai sesuatu karunia-Nya yang paling berharga bagi umat manusia, bukan saja memandang kepada perkembangan bangsa manusia, tetapi juga berhubung dengan kebahagiaan manusia secara jiwa raga di bumi ini. ${ }^{28}$

Menurut Homrighausen menulis bahwa:

Seluruh penyataan Tuhan diterangkan dengan memakai bandingan suasana dan keadaan keluarga, Allah mau disebut Bapa, dan kita ini menjadi anak-anak-Nya. Oleh karena itu pokok-pokok besar dari kepercayaan Kristen, baik mengenai apa yang kita percaya tentang

${ }^{25}$ Bambang Garang, Pola Pendidikan Anak Masyarakat Dayak dalam Transformasi Di Era Globalisasi, (Jakarta: Disertasi, 1999), 7

${ }^{26}$ J.I Packer, Merrill C. Tenney dan William White , Jr. Bible Almanac I , (Malang: Gandum Mas, 2003.), 846.

${ }^{27}$ E.G Homrighausen dan I.H Enklaar, Pendidikan Agama Kristen, (Jakarta: BPK Gunung Mulia, 2001), 130; band. Yeremia 29: 4-7

${ }_{28}$ Ibid, dalam Perjanjian Baru meceritakan banyak keluarga saleh mulai dari Yusuf, Maria dan Tuhan Yesus semasa mudanya di Nasaret, rumah tangga tiga bersaudara Maria, Marta, Lazarus di Beania, keluarga Yohanes Markus di Yerusalem, keluarga Lidia di Filipi, keluarga Timotius dengan ibunya Eunike dan neneknya Lois yang saleh di Listra. 
Allah dan ajaran keselamatan, sebaiknya mulai dipelajari dalam lingkungan keluarga Kristen, sehingga dengan sendirinya dapat dialami anak-anak dalam hubungan di lingkungan rumah-tangga. ${ }^{29}$

\section{Mengajarkan Anak pada Iman secara Nyata}

Di dalam keluarga, anak mulai mengerti apakah iman percaya itu. Anakanak muda pun belajar menghormati dan menaati orangtuanya, agar apa yang diajarkan oleh orangtua untuk menghormati orangtua di bumi, sejalan dengan mematuhi Bapa Pencipta di dalam surga. Dalam rumah tangga anak-anak belajar mengasihi sesamanya dan berkorban bagi yang lebih lemah atau berkekurangan dari dia. Dalam pergaulan rumah tangga dengan sendirinya anak-anank dididik untuk memikul tanggungjawab masing-masing terhadap tugas dan kewajibannya. Dengan demikian pertumbuhan anak dalam keluarga menjadi bayangan baginya dari tata tertib keluarga Allah Bapanya, dan suatu pertolongan yang besar faedahnya bagi hidup mausia. Demikianlah rumah tangga Kristen dapat merupakan bayangan dari gereja, bahkan dari Kerajaan Allah. ${ }^{30}$

Menurut Hall, masa remaja diumpamakan sebagai Storm and Stress oleh karena masa remaja adalah sebagai periode yang penuh dengan konflik dan ketidakpastian. Remaja tidak hanya berinteraksi dengan orangtua sebagai figur otoritas, namun di saat yang bersamaan, ia pun berhadapan dengan guru, kerabat dekat, teman, atau anak-anak yang lebih muda usianya; bahkan berhadapan dengan lembaga-lembaga formal dan non formal, di mana seluruhnya mensyaratkan perilaku yang memposisikannya bukan lagi sebagai anak-anak namun sudah sebagai orang dewasa. ${ }^{31}$ Selanjutnya menurut Gunarsa, perkembangan moral remaja banyak dipengaruhi oleh lingkungan di mana ia hidup. Tanpa masyarakat/lingkungan, aspek moral remaja tidak berkembang. Nilai-nilai moral yang dimiliki remaja lebih merupakan sesuatu yang diperoleh dari luar. Remaja belajar dan diajar oleh lingkungannya mengenai bagaimana ia harus bertingkah laku yang baik dan bertingkah laku yang bagaimana yang dikatakan salah atau tidak baik. Lingkungan ini dapat

${ }^{29}$ E.G Homrighausen dan I.H Enklaar, Pendidikan Agama ..., 130

30 Ibid., Pendidikan Agama Kristen haruslah bertujuan membawa anak didik "Mengenal Allah sebagai Pencipta dan Pemerintah seluruh alam semesta ini, dan Yesus Kristus sebagai Penebus, Pemimpin dan Penolong mereka...."

${ }^{31}$ Jeffrey S. Tunner \& Donald B. Helms, Life Span Development, (Orlando Hots: Rinehart and Winston, Inc., 1995), 410 
berarti orangtua, saudara-saudara, teman-teman, guru-guru dan sebagainya. ${ }^{32}$ Dengan demikian keluarga merupakan lingkungan pertama bagi seorang anak, dari keluarga yang memberi pengaruh yang sangat besar bagi perkembangan kepribadian seorang anak. Hal senada juga dikemukakan oleh Garang bahwa keluarga merupakan tempat yang strategis untuk merubah dan mengembangkan nilai-nilai budaya, norma-norma, melatih emosi dan kepribadian anak serta memaknai kehidupan sehingga dapat hidup lebih layak dan berarti di masyarakat. ${ }^{33}$

\section{Menyiapkan Lingkungan Anak Tanpa Rasa Takut}

Menurut Hadiwinoto bahwa keluarga Kristen yang ideal dan sempurna sebenarnya tidak ada. Melalui penelusuran dari sejarah sosiologi agama, nyata bahwa pola semula yang dipakai jemaat-jemaat dalam Perjanjian Baru adalah semacam ikatan keluarga, suku, marga (Tribal Family System). Pola ini kemudian berkembang menjadi pola keluarga besar (Extended-Family, Joint Family) yang masih hidup di daerah rural di seluruh dunia sampai sekarang. Kemudian, sebagai akibat dari urbanisasi, migrasi, industralisasi, modernisasi, maka keluarga besar itu makin menciut menjadi keluarga batih yang terdiri dari ayah, ibu dan anak-anak.

Hal yang menentukan adanya suatu keluarga Kristen atau tidak, bukan struktur keluarga, tetapi keluarga yang melaksanakan pendidikan agama Kristen, menghadirkan nilai-nilai Kristen di tengah-tengah keluarga. Mengingat sifat hubungan orang tua dan anak yang menyangkut hubungan emosional, afektif, dan intensitas pergaulan keduanya maka orang tua yang mempunyai tanggungjawab primer dalam pendidikan anak-anak. Dalam keluarga dapat dibina kualitas hidup rohani yang mendasar dan terbaik. Dalam hal ini, bukan dalam arti pengetahuan kognitif melalui suatu kemampuan berpikir, tapi dalam kepada relasi cinta kasih, dosa-pengampunan, teladan hidup dan sebagainya. ${ }^{34}$ Jadi keluarga juga berperan di dalam pembentukan perkembangan moral seorang remaja.

Menurut Chafin ada lima pengertian mengenai keluarga yaitu: pertama, keluarga merupakan tempat untuk bertumbuh, menyangkut tubuh, akal budi, Mulia, 2003)

${ }^{32}$ Singgih Gunarsa, Psikologi Perkembangan anak dan Remaja, (Jakarta: Gunung

${ }_{33}$ Bambang Garang, Disertasi Pola Pendidikan Anak Masyarakat Dayak dalam Transformasi Era Glonalisasi, (Jakarta: IKIP Jakarta, 1999), 6

${ }^{34}$ N.K Admadja Hadiwinoto, Dialog dan Edukasi , (Jakarta: BPK Gunung Mulia, 2010), 282-283 
hubungan sosial, kasih dan rohani. Manusia diciptakan menurut gambar Allah sehingga mempunyai potensi untuk bertumbuh dan merupakan tempat untuk memberi energi, perhatian, komitmen, kasih, dan lingkungan yang kondusif untuk bertumbuh dalam segala hal ke arah Kristus Yesus; kedua, keluarga merupakan pusat pengembangan semua akativitas. Dalam keluarga setiap orang bebas mengembangkan karunianya masing-masing. Di dalam keluarga, landasan kehidupan anak dibangun dan dikembangkan; ke-tiga, keluarga merupakan tempat yang aman untuk berteduh saat ada badai kehidupan; keempat, keluarga merupakan tempat untuk mentransfer nilai-nilai, laboratorium hidup bagi setiap anggota keluarga dan saling belajar hal yang baik; ke-lima, keluarga merupakan tempat timbulnya permasalahan dan penyelesaiannya. ${ }^{35}$

\section{Adanya Upaya untuk Terus Menerus Memperlengakpi Diri bagi Kepentingan Anak}

Menurut Nuhamara bahwa: "gereja perlu melakukan usaha-usaha untuk menolong para orang tua memainkan peranannya sebagai pendidik utama bagi anak-anak mereka." 36

Dalam hal ini, beberapa hal praktis yang perlu dilakukan gereja. Pertama, perlu diadakan kegiatan pembinaan yang melengkapi orangtua dengan pemahaman tentang iman Kristen dalam berbagai dimensi. Kedua, materi yang diberikan perlu mencakup pengetahuan tentang perkembangan anak. Sehingga iman Kristen dapat disampaikan dengan cara yang sesuai dengan tingkat perkembangan anak. Ke-tiga, gereja harus membentuk kelompok pendudukung yang terdiri dari orang-orang yang memahami perkembangan anak dengan baik, untuk menjadi fasilitator dalam rangka menolong para orangtua mendidik anaknya dengan baik. Ke-empat, gereja secara lokal maupun bersama-sama dapat menghasilkan bahan ajar/pendidikan untuk anak dalam dalam keluarga. Sebab Pendidikan Agama Kristen tidak hanya berlangsung di Sekolah Minggu pada hari Minggu saja, tetapi juga dalam keluarga. Oleh karena itu perlu dibuat bahan ajar yang dapat dipakai dalam keluarga. Bahan ajar tersebut tersedia dalam berbagai bentuk, tidak hanya dalam bentuk tertulis tetapi juga kaset rekaman, kaset video, dan lainlain. $^{37}$

${ }^{35}$ Kennath Chafin, Is There a Family in the House?, (Texas: World Wide Publication, 1978)

${ }^{36}$ Daniel Nuhamara, Pembimbing PAK, (Bandung: Jurnal Info Media, 2007), 63

${ }^{37}$ Daniel Nuhamara, Pembimbing $P A K \ldots, 64$ 


\section{SIMPULAN}

Menurut Undang-undang no 10 Tahun 1992, tentang Perkembangan Kependudukan dan Pembangunan Keluarga Sejahtera Bab 1 Pasal 1 butir 10: disebutkan bahwa keluarga adalah unit terkecil dalam masyarakat yang terdiri dari suami isteri atau suami-isteri-anak, ayah-anak, atau ibu anak. ${ }^{38}$ Dimensi Kristen sangat penting sebagai kaidah, norma, referensi, model tolok ukur dari seluruh performance pendidikan Kristen, serta menjadi "Imitatio Christi" yang kemudian mengaktualisasikan nilai-nilai Kristen dalam perilaku etis. ${ }^{39}$ Secara khusus karena keluarga menjadi pilar utama tempat pemeliharaan dan pelatihan iman.

Tugas dan peran orangtua dalam menanamkan nilai-nilai keluarga bagi pembinaan iman anak remaja di zaman now ini menjadi sangat vital dan mendasar bagi kehadiran keluarga Kristen, oleh karena apabila dilihat dari makna dalam bahasa Indonesia makna dari kata keluarga yang dapat diartikan sebagai suatu unit keluarga yang terdiri dari pasutri dan anak-anak, atau istilah keluarga dapat juga diartikan seisi rumah atau mereka yang hidup di bawah satu atap dan satu pemimpin. ${ }^{40}$ Peranan Pemimpin dalam keluarga adalah orangtua yang beriman kepada Yesus Kristus sebagai dasar berdirinya keluarga (I Kor. 3:11; 11:3).

Jadi tugas dan peran orangtua dalam menanamkan nilai-nilai keluarga bagi pembinaan iman anak remaja sangat signifikan di zaman now ini. Menurut Solaeman bahwa pengertian keluarga dalam arti yang lebih luas adalah ikatan yang meliputi semua pihak yang ada hubungan darah, atau yang disebut dengan clan atau marga, dan dalam arti sempit adalah hubungan darah antar keluarga inti yang terdiri atas ayah, ibu, dan anak. ${ }^{41}$ Sehingga, tugas orangtua dalam melibatkan anak remajanya dalam mewujudkan nilai-nilai kristiani menjadi sangat penting bagi penananam fondasi gereja selanjutnya. Kartini Kartono menyebutkan bahwa keluarga merupakan unit sosial terkecil yang memberikan fondasi primer bagi perkembangan anak. Sehingga, tugas terpenting bagi gereja adalah menyiapkan fondasi yang kuat bagi lingkungan

\footnotetext{
${ }^{38}$ Jason Lase, Pengaruh Lingkungan Keluarga dan Sekolah terhadap Siswa, (Jakarta: Program Pascasarjana UKI, 2005), 35 “...dalam sistem kekerabatan di Indonesia keluarga itu menampung juga kakek, nenek, dan anggota keluarga yang mempunyai ikatan kerabatan...”

${ }^{39}$ Weinata Sairin, Identitas dan Ciri Khas Pendidikan Kristen di Indonesia, (Jakarta: BPK.Gunung Mulia, 2000), 114

${ }^{40}$ Marulak Pasaribu, Pernikahan dan Keluarga Kristen, (Batu: Departemen Literatur YPPII, 2005), 12

${ }^{41}$ M.I Solaeman, Pendidikan dalam Keluarga, (Bandung: Alfabeta, 1994), 5-6
} 
keluarga, sebagai lingkungan utama gereja (selain lingkungan sekitar dan lingkungan sekolah), agar para orangtua ikut berperan dan memberikan nuansa pada perkembangan anak remaja di zaman now; oleh karena baik buruknya struktur keluarga dan masyarakat sekitar memberikan pengaruh baik atau buruknya pertumbuhan kepribadian anak. ${ }^{42}$

\section{DAFTAR PUSTAKA}

...................,

2000 Alkitab. Jakarta, Lembaga Alkitab Indonsia

Garang, Bambang,

1999 Pola Pendidikan Anak Masyarakat Dayak dalam Transformasi Di Era Globalisasi. Jakarta: Disertasi

Nuhamara, Daniel, 2007 Pembimbing PAK. Bandung: Jurnal Info Media

Irwanto, Danny Yatim, 1993 Kepribadian, Keluarga dan Narkotika. Jakarta: Penerbit Arcan

Papalia, Diane E. \& Sally Wendkos, 1998 Olds, Human Development. Boston: McGraw - Hill Company Inc

Homrighausen, E.G dan I.H Enklaar, 1974 Pendidikan Agama Kristen. Jakarta: BPK Gunung Mulia

Hurlock, Elisabeth,

1974 Personality Development. New Delhi: McGraw-Hill Publishing Co,Ltd

${ }^{42}$ Kartini Kartono, Patologi Sosial 3, Gangguan-gangguan Kejiwaan, (Jakarta: Rajawali, 1986b), 57 
Harianto GP,

2012 Pendidikan Agama Kristen Dalam Alkitab \& Dunia

Pendidikan masa Kini. Yogyakara: Andi Offset

Lase, Jason,

2005 Pengaruh Lingkungan Keluarga dan Sekolah terhadap Siswa. Jakarta: Program Pascasarjana UKI

Packer, J.I, Merrill C. Tenney dan William White, Jr.

2003 Bible Almanac I . Malang: Penerbit Gandum Mas

Tunner, Jeffrey S. \& Donald B. Helms,

1995 Life Span Development. Orlando Hots: Rinehart and Winston, Inc.

Kartono, Kartini,

1986 Patologi Sosial 3, Gangguan-gangguan Kejiwaan. Jakarta:

Rajawali

Chafin, Kennath,

1978 Is There a Family in the House? Texas: World Wide Publication

Pasaribu,Marulak,

2005 Pernikahan dan Keluarga Kristen. Batu: Departemen Literatur YPPII

Solaeman, M.I,

1994 Pendidikan dalam Keluarga. Bandung: Alfabeta

Hoffman, M.L.,

1970 Conscience, Personality and Socialization Techniques. In

Human Development

Muktar, Niken Ardiyanti, Erna Sulistiyanngsih,

2001 Konsep Diri Remaja. Jakarta: PT. Rakasta Samasta

Hadinoto, N.K Atmadja, 
2010 Dialog dan Edukasi Keluarga Kristen dalam Masyarakat Indonesia. Jakarta: BPK. Gunung Mulia

Lilik K, Paulus,

2010 Prinsip dan Praktik Pendidikan Agama Kristen Agama Kristen. Yogyakarta. Andi Ofset

Gunarsa, Singgih D.,

1989 Psikologi Muda-mudi. Jakarta: BPK. Gunung Mulia

Gunarsa, Singgih D.,

2003 Psikologi Perkembangan anak dan Remaja. Jakarta: Gunung Mulia

Sarwono, S.W.,

1989 Psikologi Remaja. Jakarta: Rajawali

1992 Psikologi Lingkungan. Jakarta: Grasindo

Ward, Ted,

1979 Nilai Hidup di mulai dari Keluarga. Malang: Gandum Mas

Nasution, S.,

1982 Berbagai Pendekatan Dalam Proses Belajar-Mengajar.

Jakarta: Bina Aksara

Tong, Stephen,

2007 Keluarga Bahagia. Surabaya: LRII, 2007

Sudarsono,

1995 Kenakalan Remaja. Jakarta: Rineka Cipta

Sairin, Weinata, $2000 \quad$ Identitas dan Ciri Khas Pendidikan Kristen di Indonesia. Jakarta: BPK.Gunung Mulia 